\title{
Systematic review of outcome measures in trials of pediatric anaphylaxis treatment
}

\author{
Tamar Rubin ${ }^{1}$, Jacqueline Clayton ${ }^{1}$, Denise Adams ${ }^{1,2}$, Hsing Jou ${ }^{1,2}$, Sunita Vohra ${ }^{1,2,3^{*}}$ \\ From Canadian Society of Allergy and Clinical Immunology Annual Scientific Meeting 2013 \\ Toronto, Canada. 3-6 October 2013
}

\section{Background}

Considerable heterogeneity has been observed in the selection and reporting of disease-specific pediatric outcome measures in randomized controlled trials (RCTs) [1]. This makes interpretation of results and comparison across trials challenging [2]. Outcome measures in pediatric anaphylaxis trials have never previously been systematically assessed [3]. This systematic review (SR) will identify and assess outcome measures used in RCTs of anaphylaxis treatment in children. As a secondary objective, this SR will assess the evidence for current treatment modalities for anaphylaxis in the pediatric population.

\section{Methods}

We searched MEDLINE, EMBASE, The Cochrane Library, Cochrane Central Register of Controlled Trials (CENTRAL), and CINAHL from 2001 until December

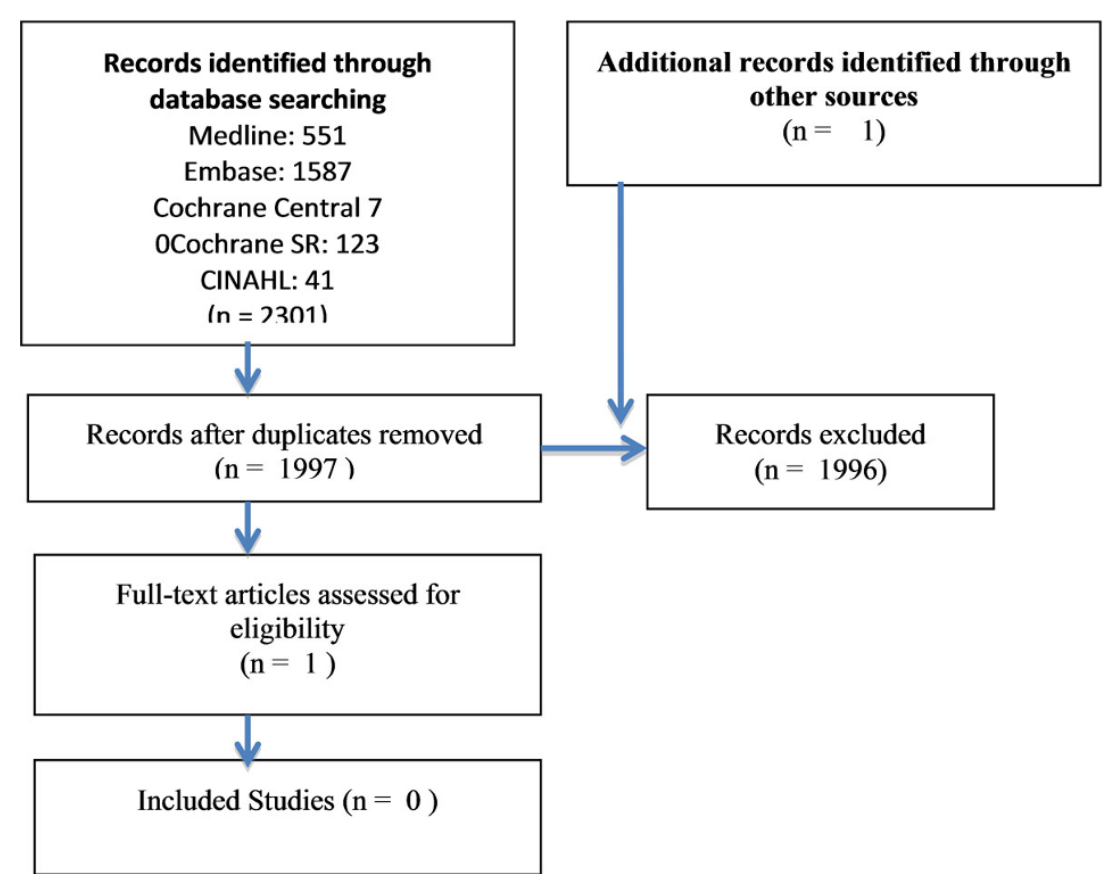

Figure 1 Search Flow Diagram

\footnotetext{
* Correspondence: svohra@ualberta.ca

'Department of Pediatrics, University of Alberta, Edmonton, Alberta, Canada
} Full list of author information is available at the end of the article 
2012. We also searched websites listing ongoing trials. We included randomized and controlled trials of anaphylaxis treatment in patients $0-18$ years of age. Two authors independently assessed articles for inclusion.

\section{Results}

No published studies fulfilled the inclusion criteria (Fig 1).

\section{Conclusions}

There is an alarming absence of RCTs evaluating the treatments for anaphylaxis in children. High quality studies are needed and are possible to design, despite the severe and acute nature of this condition. Consensus about the selection and validation of appropriate outcome measures will enhance the quality of research and improve the care of children with anaphylaxis.

\section{Systematic review registration}

\section{CRD42012002685}

\section{Authors' details}

'Department of Pediatrics, University of Alberta, Edmonton, Alberta, Canada. ${ }^{2}$ CARE Program, University of Alberta, Edmonton, Alberta, Canada.

${ }^{3}$ Department of Public Health Sciences, University of Alberta, Edmonton, Alberta, Canada.

Published: 3 March 2014

\section{References}

1. Clarke M: Standardising outcomes for clinical trials and systematic reviews. Trials 2007, 8:39.

2. Williamson PR, Gamble C, Altman DG, Hutton JL: Outcome selection bias in meta-analysis. Stat Methods Med Res 2005, 14:515-524.

3. Sinha I, Jones L, Smith RL, Williamson PR: A systematic review of studies that aim to determine which outcomes to measure in clinical trials in children. PLoS Med 2008, 5(4):e96.

doi:10.1186/1710-1492-10-S1-A36

Cite this article as: Rubin et al:: Systematic review of outcome measures in trials of pediatric anaphylaxis treatment. Allergy, Asthma \& Clinical Immunology 2014 10(Suppl 1):A36.

Submit your next manuscript to BioMed Central and take full advantage of:

- Convenient online submission

- Thorough peer review

- No space constraints or color figure charges

- Immediate publication on acceptance

- Inclusion in PubMed, CAS, Scopus and Google Scholar

- Research which is freely available for redistribution

Submit your manuscript at www biomedcentral.com/submit 